\title{
NEGATING STATES LOSSES APPROACH ON PUNISHMENT OF CORRUPTION
}

\author{
Fransiskus Arkadeus Ruwe
}

fransiskus@gmail.com

\begin{abstract}
The criminal act of corruption is viewed from the formulation of the offense Article 2 of Act No.31 Of 1999 concerning the Crime of Corruption is an economic offense caused by an act against the law, as a logical consequence of the Against the Law is to restore or negate the state's losses, achieve justice, utility and legal certainty, with priority on utility. Not becoming prevalent zero losses concept applied because it is trapped in the prevalence of enforcing the law of corruption with the priority on legal certainty, it requires the progressive and militant spirit of the judges but a high and long commitment and a relatively long time to start with the target group within the judge to get out of the routine of law enforcement that is running.
\end{abstract}

Keywords: Corruption; Criminalization; Negates State Losses.

\section{A. INTRODUCTION}

After the reformation in line with the establishment of the Corruption Eradication Commission on December 29, 2003, the establishment of a corruption court spread across provinces is certainly directly proportional to the increase in the number of corrupt cases, the inclusion of the achievements mentioned in the annual report of KPK cited daily Bernas.com ${ }^{1}$ dated 17 January 2017 that during 2016, the Commission conducted execution of 81 judicial decisions that have subsequent legal force of this action, the KPK managed to save the state money worth hundreds of billions, more than 497.6 billion rupiah has been put into the state treasury in the form of PNBP from Handling corruption criminal case, "KPK Chairman Agus Rahardjo said in a press conference on the performance of the

1 www.harianbernas.com, Accessed on 09 January 2017. end of the of, at the KPK's Jakarta office on Monday (09/01/16), not less in prestige as quoted by Tribunnews.Com, Jakarta2, reported throughout 2016, the Attorney General's Office executed the convicted person Corruption to prisoners there are 1557 convicted, managed to save state money amounting to $\mathrm{Rp}$ 275.6 billion and paid the fine to the state treasury amounting to $\mathrm{Rp} 41.4$ billion, "said Head of Information Center and Law Attorney General in the late 2016 release; Submitted also by some prosecutors who have handled corruption corruption process convey the cost of handling corruption cases since the investigation until the execution of the decision/execution ranged from Rp.150.000.000 to Rp.200.000.000.

Without intending to break down the achievements of the Attorney General's Office and the KPK reveal,

2 www.tribunnews.com, Accessed on 04 January 2017. 
investigate and prosecute corruption and restore the state's finances, it is of course also need to add to the content of the whole space of thought that law enforcement in the field of corruption is understood to also always be able to answer the implementation of the basic thoughts which is the background and the reason for the making of corruption law is nothing but to waive the state losses because by restoring the state's loss, it has also restored the social and economic rights of the society widely as the ideals of the Indonesian nation to advance the common prosperity in the Preamble of the the 1945 Constitution, so that corruption is always understood and experienced as an extra ordinary crime can have a real impact on the welfare of society, the logical consequence of all elements of the nation also understand that eradicating corruption will not be more effective if done simply by ordinary or linear criminal justice system of prosecution and punishment (imprisonment, fines, surrogates) without taking into account the economic recovery of the country that leads to the welfare of society.

Economic instruments in law enforcement are not a new concept and taboo but are still in the corridor of law that is to pay attention to the types of criminal penalties in Article 10 of the Criminal Code, article 1365 of the Civil Code about the Unlawful Act, and Article 18 paragraph (1) Sub-Paragraph b of the Corruption Law concerning additional punishment pay substitute money, and then explicitly formulated in article 222 of Act No.8 Of 1981 on the Criminal Procedure Code which reads paragraph
(1) Anyone who is sentenced shall be charged with paying the cost of the case and in the case of an independent verdict or escape from any lawsuit, The cost of the case shall be borne by the state. (2) In the event that the defendant has previously applied for an exemption from the payment of a court fee under certain conditions with the court's consent, the cost of the case shall be borne by the state; Implied also to the meaning of Article 6 of Act No.46 Of 2009 concerning the Court of Corruption, which includes Money Laundering (Act No. 8 of 2010 on Prevention and Eradication of Money Laundering) in the competence of the corruption court by a method handedly folow the money to impoverish the corruptors. Departing from these juridical bases stimulated the question of whether the cost incurred by the state to disclose a criminal act of corruption had been paid with the imposed penalty, as the information obtained by hukumonline.com ${ }^{3}$ turned out to be the details of the costs allocated in each law enforcement agency were not the same. At the Prosecutor's Office, for example, the total cost of one corruption case to be thorough is 200 million rupiah. The details, 25 million stages of inquiry; 50 million stages of investigation; 100 million stages of prosecution. The rest, another 25 million, is used for the execution fee of the verdict. In Police the cost of investigation and investigation of corruption cases is also not much different, the total Rp208 million per case, and in the District Court

3 www.hukumonline.com, Accessed on Thursday 12 May 2016. 
is very low in the budget scale of the Supreme Court, also conveyed by two prosecutors who have handled corruption process cost handling corruption case since the investigation up to the execution of the verdict reached 200 million rupiah, plus the cost during the convict was in prison, the numbers may be different but there is almost certainly a money paid for the job.

Tracing to the theoretical order is Gustav Radbruch a legal philosopher and a prominent German legal scholar who teaches the concept of three basic legal elements. These three basic concepts were put forward in the era of World War II. The legal objectives stated by various experts are also identified as the objectives of the law, while the three objectives of the law are certainty, justice, and usefulness inspires the correlation between economic instruments in law enforcement objectives ie benefits that benefit parameters closer to economic calculations, of the theory economic parameters need to be pushed forward to appear to represent the benefits of law enforcement objectives in the field of corruption, without any other social benefits.

Departure from the phenomenon, then in the middle of the wild solutions are common, the approach of economic benefits in law enforcement of corruption is another step that is still promising and not a norm that certainly brings serious consequences, both in the debate and the results. This research is qualitative inductive research that emphasizes in-depth study on concept, theory, doctrine related to the nature of law enforcement purpose especially criminal law enforcement. The approach used is philosophical jurisdiction, exploring, looking for and discovering the values behind the phenomena of law enforcement in the field of criminal acts of corruption especially from the aspect of economic value as an idea to negate losses of state zero losses / negating state losses.

Sources of data are secondary data supported by primary data obtained from stakeholders who are directly involved in efforts to eradicate corruption, and secondary data from literature sources, including literature books, documents, reports, legislation, judgments, data collection techniques by conducting in-depth literature review of legislation, verdict of judges, investigator investigation files, DIPA of the Supreme Court, the Police of the Republic of Indonesia and the Attorney General of the Republic of Indonesia, journals relating to criminal acts of corruption. The analysis is done by descriptive the results of the study to build the concept of eliminating state losses in the penal system of fines penalty in the criminal act of corruption.

\section{B. DISCUSSION}

\section{Sentencing Purpose}

The various theories of punishment purposes it is concluded that there is an expectation that will be fulfilled by punishment, and if pulled back can come to the original question whether the definition of the law and whether criminal punishment is the goal of law, and the answer lies 
in the philosophical theories that never satisfactorily satisfy . Objectives of law by Ahmad Ali in the book Revealing Legal Theory \& Judicial Theory: Including Legisprudence Volume 1 Initial understanding, dividing the grand theories of legal objectives into three group approaches namely first western legal theory (Classical theory and modern theory), both Eastern theories and the three theories of Islamic law, with the following description:

Classic Theory:

1.The ethical theory: the purpose of the law solely for the realization of justice.

2.Utilititive theory: The purpose of the law solely to realize the utility (utility).

3.Legal Theory: The purpose of the law is solely to realize legal certainty.

Modern theory:

1.Standard priority theory: The objectives of law include justice, benefit and legal certainty.

2. Theory of casuistic priority: The objectives of law include justice-legal certainties, in order of priority, proportionally, in accordance with the case at hand and want to be resolved. ${ }^{4}$ The theory of the objectives of Eastern law does not focus on certainty but on justice is harmony,

4 Achmad Ali, 2009, Menguak Teori Hukum (Legal Theory) \& Teori Peradilan (Judicialprudence): Termasuk Interpretasi Undang-Undang (legisprudence) Volume 1 Pemahaman awal, Perdana Media Group, Jakarta, p. 212-213. and harmony is peace. ${ }^{5}$ Achmad Ali further said the purpose of Islamic law in principle is how to realize kemafaatan to all mankind that includes the benefits in life in the world and in the hereafter. These theories represent a great portrait of ideal ideals of law that represents the way of thinking and acting of the nations in the world to post a phenomenon, of course without any further questioning that the Indonesian nation has its own legal ideal that is inherent with the ideal of state goals in the opening of the Law Basic 1945, which we think is the third praxis The grand objective of the law always appears at the right moment in law enforcement in Indonesia, therefore it is not wrong to argue and follow the opinion of one or several theory of western law objectives introduced by Gustav Rabruch that the purpose of law is to achieve justice (Justice), utility and legal certainty, but in various literatures introduces eastern legal purposes that are still professionally adhered to in Japan, namely: peace as Satjipto Rahardjo quotes Robert S. Ozaki's opinion of how the Japanese are punished, Wrote "The Meiji codes, were faces, a surface ornament affected in the modernity in Western terms, $^{6}$ The language, ideas,

5 Ibid, p.116.

6 Achmad Ali, 2002, Keterpurukan Hukum di Indonesia (Penyebab dan Solusinya), PT. Ghalia Indonesia, p. 44.

7 Andre Ata Ujan, 2009, Filsafat Hukum, Membangun Hukum Membela Keadilan, Penerbit Kanisius, p. 52. 
philosophy, and logig of the code were distinctly European", Further Aquinas's view derives from the practical ratio that the goal of law is the ultimate end of man, that is happiness, so that the law is directed to create order for the sake of achieving happiness in general, it means order is called regular only when directed to the common good or Common good, summed up by Andre Ata Ujan that the ultimate purpose of the law is nothing but the common good. $^{7}$

Starting from the philosophy of the objectives of the above law then juxtaposed with the punishment will be a question of what the reason and the intention of punishment whose answer is still in the level of philosophy that is returned again to the issue agree and disagree on a view/doctrine and the power of various theories and concepts built by the jurists depend on scientific campaigns of supporters who are generally transmitted through their respective institutions of university where theoretical theory is initiated such as progressive legal/legal theory concepts/theories developed in Undip Semarang.

In the legal scholarly circles looking for philosophical justification arguments against the purpose of punishment are substantially classified into three categories: Theory of
Revenge, the theory of Purpose and Combined theory. ${ }^{8}$

a. Theory of Revenge (absolute theory)

Based on the theory of Revenge (absolute) based on the absolute theory: that because someone has committed a crime or a crime. Criminal as a sorrow inflicted is the absolute consequence that must Imposed in retaliation to a person who commits a crime. (meaning the perpetrator must also feel what if he becomes his victim, back oriented) Every crime should be given a punishment regardless of what might arise after the punishment, that because someone has committed a crime or a crime, the theory of retaliation is embraced by Immanuel Kant, Hegel, Herbart, Stahl, Gewin, Thomas Aquino, Jean Iacques Rousseou, Hugo de Groot, Grotius, Bacarica.

b. Theory of Purpose (relative theory, improvement).

Based on the relative theory that a criminal act is not merely sanctioned by criminal sanction. A punishment should also consider the consequences that may arise after the conviction. (Future oriented), justification of criminal prosecution based on or dependent on the purpose of punishment that is to protect the community by making criminal

8 EY.Kanter dan SR.Sianturi, 2010, Asas-Asas Hukum Pidana di Indonesia dan Penerapannya, Alumni, Jakarta, p. 59 
provisions in order to give birth to a psychological impulse to a person so as to be afraid to do evil / prospective criminals (general prevention), giving educational effects for criminals, Society or communications, as a means of preventing a person from committing a crime, these adherents are Paul Anselm van Feurbach, Grolman Van Krause, Roder, Ferri, Garofalo, Frans von Litz, Van Hamel, Simons, here contained psychological coercion.

c. Combined Theory.

According to a combined theory or a combination of two earlier theories that a criminal imposition should be based on retaliation and also consider that the punishment will preserve the society. Criminalization of the element of retaliation and prevention.

From the above three theories seem to be the development of the reason for the punishment of all time, the criminal was initially imposed in retaliation for the actions of a person who is considered a crime slowly the paradigm is changed to follow the current reinforcement of liberalism and human rights.

From the various theories of punishment Romli Atmasasmita ${ }^{9}$ concluded that each flow in the penal law has had little effect on the purpose and the punishment

9 Romli Atmasasmita, 1995, Kapita Selekta Hukum Pidana dan Kriminologi, Penerbit CV. Mandar Maju, P. 85. system according to its time, the Kantian flour that developed in the 18 th century has given a warnah on the purpose of criminal punishment with a punishable punishment system Emphasizes the total isolation of criminals from the environment. While Benthamite flow has given warnah on the purpose of punishment that is reformative, namely the punishment system that focuses on the guidance of the perpetrators of crime in order to become useful citizens.

Equally important is the concept of criminal stelsel substance in RUUKUHP which is somewhat different from the criminalization paradigm in the Criminal Code, namely the purpose of criminal punishment according to the draft of Article 54 of Article 54 in the direction of social oriented means to give a larger portion of the common good, based on the weight factor and Alleviate to the perpetrator, as Abdul Ghofur Anshori said. For punishment to be fair, punishment must contain both legal and moral aspects, so that the achievement of both inner and outer tranquility, not only for lawmakers, but also society in general ${ }^{10}$.

\section{Corruption Impact On Economic}

Withdrawn from 13 articles of corruption offense in Law no. 31 of

10 Abdul Ghofur Anshori, 2009, Fisafat Hukum, Penerbit Gadjah Mada University Press, Yogyakarta, p. 5. 
1999 jo Law no. Law No. 20 of 2001, which includes unlawful acts, misusing authority that harms state finances, bribery, embezzlement in office, extortion, gratification and fraudulent conduct, implies that potential corruption virus attacks the dimensions of the apparatus / morality morality Meet the needs of the state and society especially related to public services so that systematically affect the high cost.

Indeed the relationship between corruption and poverty is based on the main conclusions of a literature study conducted by Eric Chetwynd, Frances Chetwynd and Bertram Spector in 2003 entitled "Corruption and Poverty: A Review of Recent Literature" as quoted by Wandy Nicodemus Tuturoong ${ }^{11}$, Senior Consultant working at Transparency International that corruption can not directly produce poverty. However, "corruption has direct consequences for governance and economic governance factors, which in turn lead to poverty." Broadly speaking, there are two models that can explain the relationship between corruption and poverty, which is the first model of the economy in which corruption increases directly reduce investment in the economy, create market distortions, undermine competition, and lead to marked inefficiencies With rising costs of doing business, and increasing inequalities in revenue. All of these will eventually exacerbate poverty,

11 Wandy Nicodemus Tuturoong, www,ti,or,id, Accessed on 04 October 2010. and the second is Governance, explaining that corruption primarily affects the government's governance capacity, which then has an impact on increasing poverty. Regardless of both models in the economic order, the losses can be converted into the currency that must be borne by the state and society throughout the country.

\section{Economic Principles In Criminal Law Enforcement}

The theories and concepts of law enforcement and punishment objectives described above have not provided satisfactory answers in the face of the complexity of law enforcement issues in corrupt areas that spoil corruptors (given space for public awe, comfortable living space in Correctional Institutions, Remissions etc.) Compared to the treatment of common people, so that absolute / revenge theory in the form of physical blame for convicted criminal corruption becomes meaningless as well as the theory of relative / corrective goals and combined theory; The latest development is the concept of impoverishing the corruptors who have been given the legal basis in Article 18 of Act No.31 Of 1999, Concerning the Limitations of Corruption, Law No. 8 of 2010 on Prevention and Eradication of Money Laundering Crime as a mere jargon, So that the concept of eliminating state losses due to unlawful acts of corruptors is encouraged to be tried, adopted from article 1365 of the Civil Code "Every act that violates the law 
and carries harm to others, obliges the person who causes the loss by his mistake to replace the loss"; Through an instrument of economic principles defined as an attempt to obtain certain results with the lowest possible sacrifice. Or another definition of economic principle that is a business or action in obtaining the satisfaction of a particular need with minimal sacrifice, economic principles lead to action in order to achieve effectiveness and high efficiency essentially acting with the principle of "expenditure followed by the results obtained. In carrying out the mission of eliminating state losses should begin to shift the criminalizing paradigm from offender oriented to victim-oriented victims (state, local, community affected directly from a criminal act of corruption) Taking into account also the costs incurred by the state in real terms to finance the process of a criminal case.

Juridically, the concept has no legal framework but as a progressive rarity it is worth to be examined from the aspect of its benefits at least two of the first benefits achieved by financial managers in the Indonesian National Police and the Attorney General of the Republic of Indonesia to accountable both state losses to zero losses, with benefits Others as bonuses (requires further review).

\section{CONCLUSION}

Eliminating state losses to zero at least the lowest lows do not come out from the base of law enforcement aimed at enacting Gustav Radbruch which is refracted from the aspect of enforcing the benefits of law in addition to justice and legal certainty aspects. The juridical concept of zero losses in law enforcement in the field of corruption crime has no legal framework but as a progressive rarity should be studied from the aspect of its benefits at least three benefits achieved first financial manager in the Police Agency of the Republic of Indonesia and the Attorney General of the Republic of Indonesia became accountable both losses The state becomes nil/zero losses, with other benefits as bonuses (requires further review), and most importantly the sensitivity or the economic sensitivity of judges or judges with an out-of-the-box perspective to take into account cost / cost into its decision The cost of the case of Article 222 of the Criminal Procedure Code, the three may analyze and determine the prosecution and the form of a restorative punishment, the principle that eliminating state losses is far more beneficial than just a deterrent effect.

Not enough with the progressive and militant fervor of the judges but it takes a high and long commitment and a relatively long time to start from the target group as a pioneer within the judiciary of the general judiciary, which certainly does not escape also crave harder work Again from academics, Non Governmental Organizations such as ICW, Press, CBOs and the community as an addition to ammunition or vitamin for judges who become pioneers to get out of routine understanding of law enforcement purpose being experienced. 


\section{BIBLIOGRAPHY}

Abdul Ghofur Anshori, 2009, Fisafat Hukum, Penerbit Gadjah Mada University Press, Yogyakarta.

Achmad Ali, 2002, Keterpurukan Hukum di Indonesia (Penyebab dan Solusinya), PT. Ghalia Indonesia, Jakarta.

Achmad Ali, 2009, Menguak Teori Hukum (Legal Theory) \& Teori Peradilan (Judicialprudence): Termasuk Interpretasi Undang-Undang (legisprudence) Volume 1 Pemahaman awal, Perdana Media Group, Jakarta.

Andre Ata Ujan, 2009, Filsafat Hukum, membangun Hukum, Membela Keadilan. Publisher Kanisius. Jakarta.

Artidjo Alkostar April 2009, Dimensi Kebenaran Dalam Putusan Pengadilan, Majalah Varia Peradilan ( Ikatan Hakim Indonesia) No.281/ Edisi Tahun XXIV.

E.Y. Kanter at al., 2002. Asas-Asas Hukum Pidana di Indonesia dan Penerapannya. Alumni AHM-PTHM. Jakarta.

Romli Atmasasmita. 1995. Kapita Selekta Hukum Pidana dan Kriminologi, Publisher CV. Mandar Maju. Bandung.

Wandy Nicodemus Tuturoong, www.ti.or.id, Accessed on 04 October 2010.

www.harianbernas.com, Accessed on 09 January 2017.

www.hukumonline.com, Accessed on Thursday 12 May 2016.

www.tribunnews.com, Accessed on 04 January 2017. 